\title{
Rekayasa Teknologi Penyimpanan dengan Atmosfer Termodifikasi untuk Memperpanjang Umur Simpan dalam Penanganan Pascapanen Tomat
}

\author{
Modified Atmospheric Storage Technology Engineering to Extend Shelf Life in Tomato Postharvest Handling \\ Eusabius Paul Pega, Nursigit Bintoro*, Arifin Dwi Saputro
Departemen Teknik Pertanian dan Biosistem, Fakultas Teknologi Pertanian, Universitas Gadjah Mada, Jl. Flora No. 1, Bulaksumur, Yogyakarta 55281, Indonesia
*Penulis korespondensi: Nursigit Bintoro, Email: nursigit@ugm.ac.id

Tanggal submisi: 18 Maret 2020; Tanggal revisi: 10 Juni 2020; Tanggal penerimaan: 6 Juli 2020

\begin{abstract}
ABSTRAK
Tomat adalah salah satu komoditas hortikultura yang bernilai ekonomis tinggi dan berpotensi untuk diekspor. Buah tomat memerlukan penanganan serius, terutama dalam hal peningkatan hasil, mutu, dan penanganan pascapanennya. Salah satu tahapan pascapanen produk segar hasil pertanian yang sangat penting adalah penyimpanan. Penelitian ini bertujuan untuk merancang alat yang mampu mengatur suhu dan memodifikasi komposisi gas di dalam suatu ruangan tertutup (Modified Atmosphere Storage, MAS), melakukan kajian matematis maupun statistika mengenai pengaruh komposisi gas serta variasi suhu udara ruang simpan terhadap berbagai sifat fisik buah tomat dan menentukan kombinasi perlakuan terbaik antara konsentrasi oksigen dan suhu ruang simpan untuk penyimpanan buah tomat. Penelitian dimulai dengan pembuatan peralatan MAS dengan berbagai kelengkapannya. Setelah peralatan MAS jadi, kemudian dilakukan pengujian dengan variasi perlakuan konsentrasi gas $\mathrm{O}_{2} 3 \%, 10 \%, 15 \%$, dan $21 \%$ dan suhu ruang MAS $10{ }^{\circ} \mathrm{C}, 15^{\circ} \mathrm{C}$, dan $28{ }^{\circ} \mathrm{C}$, dengan sampel buah tomat. Pengamatan dilakukan setiap hari selama 15 hari terhadap perubahan kualitas fisik buah tomat yang disimpan. Hasil penelitian ini menunjukkan bahwa peralatan MAS dapat dibuat dari bahan-bahan yang tersedia dipasaran lokal dengan hasil yang memuaskan. Penurunan konsentrasi gas $\mathrm{O}_{2}$ ruang MAS dapat dilakukan dengan mengalirkan gas $\mathrm{N}_{2}$ kedalam ruang simpan MAS. Kombinasi perlakuan variasi konsentrasi oksigen dan suhu penyimpanan berpengaruh terhadap parameter laju respirasi, susut bobot, total padatan terlarut, $\mathrm{pH}$, dan kekerasan buah. Secara umum kombinasi perlakuan terbaik adalah perlakuan dengan konsentrasi oksigen 10\% dan suhu penyimpanan $15^{\circ} \mathrm{C}$.
\end{abstract}

Kata kunci: Penyimpanan; atmosfer termodifikasi; sifat fisik; oksigen; suhu 


\begin{abstract}
Tomato is one horticultural commodity with high economic value and has a potential to be exported. Tomatoes need serious handling, especially in improving yield, quality, and its postharvest handling. One of important postharvest handling stage of agricultural fresh produces is storage. This study aims to design and to build an equipment which capable to control temperature and modify gas composition inside a closed room (Modified Atmosphere Storage, MAS) and to analyze mathematically and statistically regarding the effect of gas composition and temperature on physical qualities change of tomato. The research was started by constructing MAS equipment equipped with its several accessories. After MAS equipment had been built, then an experiment was conducted with the treatment of oxygen concentration of $3 \%, 10 \%, 15 \%$, and $21 \%$ with the storage temperatures of 10 ${ }^{\circ} \mathrm{C}, 15^{\circ} \mathrm{C}$, and $28^{\circ} \mathrm{C}$, and tomato was used as the sample. The experiment results indicated that MAS equipment could be built from local market available materials with satisfactorily results. Decrease in oxygen concentration inside MAS room could be done by flushing $\mathrm{N}_{2}$ into MAS room. Treatment combination of oxygen variation and storage temperature affected respiration rate, weight loss, total soluble solid content, $\mathrm{pH}$, and firmness of the fruit. In general, the best treatment combination was the treatment with oxygen concentration of $10 \%$ and storage temperature of $15^{\circ} \mathrm{C}$.
\end{abstract}

Keywords: Storage; modified atmosphere; physical properties; oxygen; temperature

\section{PENDAHULUAN}

Tomat adalah salah satu komoditas hortikultura yang bernilai ekonomis tinggi dan mempunyai potensi besar sebagai komoditas eksport. Konsumsi tomat segar dan olahan meningkat terus seiring dengan kebutuhan manusia pada gizi yang seimbang (Luntungan, 2012). Kehilangan kualitas maupun kuantitas selama pascapanen dari bahan pangan merupakan masalah besar diseluruh dunia. Oleh karena itu, teknologi pascapanen telah mendapat perhatian baik di negara maju maupun negara yang sedang berkembang (Mama dkk., 2016).

Salah satu tahapan pascapanen produk segar hasil pertanian yang sangat penting adalah penyimpanan. Di Indonesia penyimpanan produk segar pascapanen yang baik dan benar masih relatifjarang ditemukan pada tingkat petani maupun pedagang pengumpul. Keterbatasan pengetahuan serta peralatan mengakibatkan petani pada umumnya tidak dapat menyimpan produk segar yang telah dipanen dalam waktu yang lebih lama, sehingga hasil panen harus segera dijual meskipun harga di pasar tidak sesuai dengan keinginan para petani. Kondisi ini mengakibatkan petani selalu menderita kerugian, karena terpaksa harus menjual produk segar tersebut pada saat panen raya yang harganya relatif murah.

Tidak berkembangnya teknologi penyimpanan produk segar pascapanen telah nyata dampaknya terhadap pasar komoditas pertanian di Indonesia khususnya komoditas buah-buahan. Banjir buah-buahan inportdapatkitajumpai hampir di setiap outletpenjualandi seluruh wilayah Indonesia baik di pasar-pasar tradisional maupun di pasar-pasar modern. Upaya pemerintah untuk mengatasi masalah pascapanen hingga saat ini hampir tidak ada, selain bertumbuh suburnya praktek mafia impor dan tidak adanya kebijakan pemerintah yang serius untuk menyelesaikan permasalahan dalam bidang pertanian khususnya permasalahan pascapanen, hal ini menyebabkan Indonesia menjadi salah satu negara yang sangat tertinggal dari negara-negara berkembang lainnya dalam hal pengembangan teknologi pascapanen. Demikian juga dengan bantuan-bantuan teknis maupun peralatan terkait dengan salah satu kegiatan pascapanen, yaitu penyimpanan produk segar bagi petani hingga saat ini hampir tidak pernah ada. Sebagian besar bantuan pemerintah untuk bidang pertanian hanya difokuskan pada kegiatan onfarm seperti bantuan pupuk, benih, insektisida, traktor, mesin pemanen, dan lain-lain. Fasilitas-fasilitas untuk melaksanakan penelitian pada bidang penanganan pascapanen produk segar di Indonesia masih sangat terbatas. Kebutuhan akan fasilitas yang memadahi merupakan hal yang penting untuk dapat mengembangkan teknologi pascapanen produk segar yang berkualitas (Rahayu dan Bintoro, 2019). Tujuan dari penelitian ini adalah untuk merancang dan membuat peralatan yang dapat mengatur suhu dan memodifikasi komposisi gas dari udara yang ada di dalam suatu ruangan tertutup yang secara umum dikenal sebagai Modified Atmosphere Storage (MAS). Selanjutnya melakukan kajian matematis maupun statistika mengenai pengaruh komposisi gas serta variasi suhu udara ruang simpan MAS terhadap berbagai sifat fisik buah tomat serta menentukan kombinasi perlakuan terbaik antara konsentrasi oksigen dan suhu ruang MAS untuk penyimpanan buah tomat. 


\section{METODE PENELITIAN}

\section{Waktu dan Lokasi Penelitian}

Penelitian ini dilaksanakan pada Bulan JanuariOktober 2019 di Laboratorium Teknik Lingkungan Bangunan Pertanian, Fakultas Teknologi Pertanian, Universitas Gadjah Mada.

\section{Bahan}

Bahan-bahan untuk pembuatan peralatan MAS terdiri atas pelat besi, pelat aluminium, kayu triplek, isolator polyurethane dan styrofoam, paku, mur-baut, perekat, karet perapat, dan vernis digunakan untuk pembuatan ruang penyimpan. Sedangkan peralatan untuk memodifikasi komposisi gas terdiri atas tabung gas nitrogen, tabung gas oksigen, dan tabung gas karbondioksida yang dibeli dari PT. Samator Gas Industri Yogyakarta. Beberapa peralatan pendukung untuk mengatur dan memonitor kondisi ruang MAS terdiri atas pipa-pipa penyalur gas merk dagang PVC, sepasang kipas dengan merk dagang star tech.com, power supply, motor listrik, kabel, saklar listrik, 10 pasang baterai $A B C$ berukuran (AA). Adapun sebagai tempat sampel buah tomat yang disimpan dalam MAS berupa container plastik bervolume 6 L. Sebagai sampel penelitian adalah buah tomat masak yang masih berwarna hijau varietas Servo F1 yang diperoleh dari Pasar Induk Giwangan, Yogyakarta.

\section{Alat}

Peralatan yang digunakan dalam penelitian ini dapat dikelompokkan menjadi dua, yaitu peralatan perbengkelan yang digunakan untuk pembuatan konstruksi MAS beserta peralatan pendukungnya dan peralatan untuk pengukuran kualitas fisik sampel buah tomat yang disimpan. Peralatan perbengkelan yang digunakan meliputi gergaji kayu, gergaji besi, kwas, seperangkat obeng, palu besi, solder, gunting, pisau, dan tang. Peralatan pendukung untuk mengatur kelembaban dalam ruang MAS menggunakan mist maker ultrasonic automizer humidifier berkapasitas 0,5 L/jam dan berdimensi 36×36×25 mm dengan panjang kabel 90 $\mathrm{cm}$. Konsumsi listrik peralatan MAS diukur dengan watt meter yang diproduksi oleh Power Merchant dengan bobot $400 \mathrm{~g}$ dan berdimensi $15,5 \times 7 \times 3,5 \mathrm{~cm}$. Untuk memonitor konsentrasi gas $\mathrm{O}_{2}$ dan $\mathrm{CO}_{2}$ dalam ruang MAS maupun respirometer digunakan $\mathrm{O}_{2}$ dan $\mathrm{CO}_{2}$ analyzer Quantek 902D berdimensi 249×102×254 mm dengan berat $4,4 \mathrm{~kg}$ buatan Amerika Serikat. Demikian juga digunakan sensor suhu dan kelembaban dengan resolusi $0,1^{\circ} \mathrm{C}\left(0,1^{\circ} \mathrm{F}\right) / 1 \% \mathrm{RH}$ dan berdimensi $115 \times 64 \times 18 \mathrm{~mm}$, thermostat dengan merk dagang W1209 NTC sebagai peralatan untuk memonitor suhu dan kelembaban ruang MAS. Monitoring suhu juga dilakukan pada beberapa titik dalam ruang MAS dengan menggunakan thermocouple 12 channel dengan merk Extech TM500.

Sedangkan peralatan untuk analisis kualitas fisik buah tomat yang disimpan antara lain refraktometer dengan merk Star berdimensi 55×31×105 mm dengan bobot $100 \mathrm{~g}$, untuk mengukur total padatan terlarut. Alat uji tekan (texture analyzer) yang dihubungkan langsung ke komputer dengan aplikasi LV-1000, untuk mengukur kekerasan buah tomat. Colormeter dengan merk TES 135 dan berdimensi 172x118x46 $\mathrm{mm}$ dengan bobot $220 \mathrm{~g}$, untuk mengukur perubahan warna buah tomat. Timbangan analitik dengan merk Balance XPR105 berkapasitas maksimum $120 \mathrm{~g}$, untuk mengukur perubahan berat buah tomat. Ph meter merk Xingweqiang buatan China, digunakan untuk pengukuran tingkat keasaman dari sampel buah tomat. Sedangkan pengukuran laju respirasi dilakukan menggunakan respirometer dengan metode statis (static method).

\section{Prosedur Penelitian}

\section{Perancangan dan pembuatan alat}

Langkah pertama dalam perancangan dan pembuatan alat Modified Atmosphere Storage (MAS) ialah membuat ruang penyimpan berbentuk kotak dengan ukuran $90 \times 52 \times 75 \mathrm{~cm}$ yang dilengkapi dengan mesin pendingin, mist maker ultrasonic automizer humidifier, 2 buah kipas, thermostat, sensor suhu, dan pintu untuk memasukkan dan mengeluarkan sampel bahan tomat yang disimpan. Kotak dilengkapi dengan lubang masuk dan lubang keluar gas untuk mengatur komposisi gas yang ada di dalamnya, terutama untuk menurunkan komposisi gas oksigen (Gambar 1). Langkah yang kedua yaitu melakukan running test untuk mengetahui kinerja perlatan dalam menciptakan kondisi udara ruang yang berbeda-beda baik dalam hal temperatur maupun komposisi gas di dalamnya. Langkah yang terakhir yaitu melakukan penelitian penyimpanan buah tomat dan melakukan pengukuran secara periodik terhadap berbagai parameter yang dibutuhkan seperti laju respirasi, kadar air, susut bobot, perubahan warna, tekstur, pH, total padatan terlarut, diameter buah, dan kadar gula. Adapun bagan alir proses penelitian ini dapat dilihat pada Gambar 2.

\section{Proses pembuatan campuran gas}

Untuk membuat komposisi gas dalam ruang MAS sesuai yang diinginkan, dilakukan dengan pengaliran 


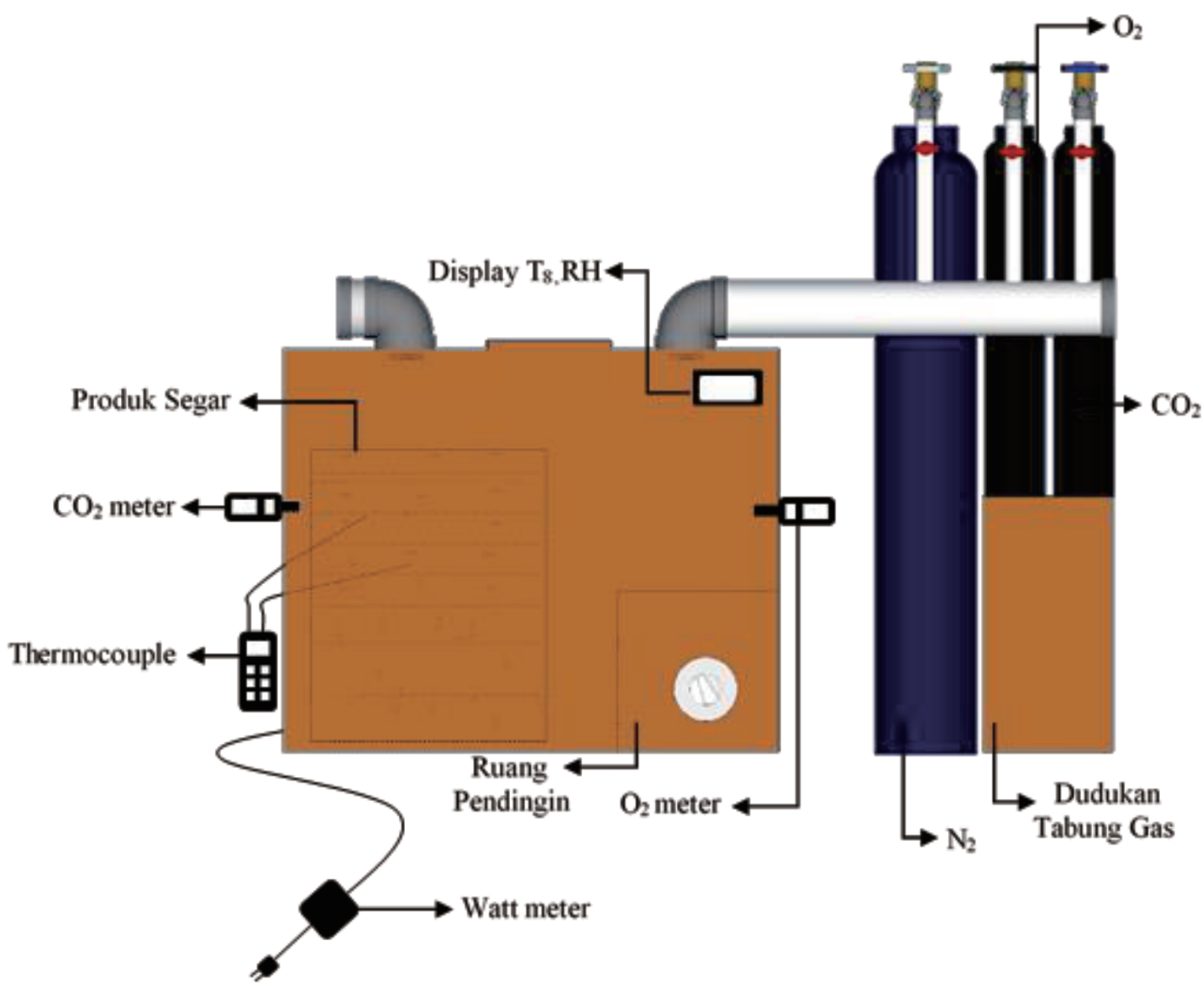

Gambar 1. Bagan skematis peralatan Modified Atmosphere Storage (MAS)

gas $\mathrm{O}_{2}, \mathrm{CO}_{2}$, dan $\mathrm{N}_{2}$ dari ketiga tabung gas yang dipasang sesuai keperluan. Penurunan gas $\mathrm{O}_{2}$ dilakukan dengan cara mengalirkan gas $\mathrm{N}_{2}$ ke dalam ruang MAS sampai konsentrasi gas $\mathrm{O}_{2}$ yang dikehendaki tercapai. Apabila konsentrasi gas $\mathrm{O}_{2}$ dalam ruang MAS terlalu rendah, maka dilakukan peningkatan konsentrasi gas $\mathrm{O}_{2}$ dengan mengalirkannya dari tabung gas $\mathrm{O}_{2}$. Sedangkan pengaliran gas $\mathrm{CO}_{2}$ dalam penelitian ini tidak dilakukan, karena tidak ada perlakuan variasi konsentrasi gas $\mathrm{CO}_{2}$ dalam penelitian. Gas $\mathrm{CO}_{2}$ dialirkan hanya apabila dalam pengaturan konsentrasi $\mathrm{CO}_{2}$ dalam ruang MAS terlalu rendah, dibawah 0,03\%. Konsentrasi gas $\mathrm{O}_{2}$ yang dialirkan ke dalam ruang simpan disesuaikan dengan variasi perlakuan, pada penelitian ini konsentrasi gas $\mathrm{O}_{2}$ yang digunakan adalah $3 \%, 10 \%, 15 \%$, dan $21 \%$. Sedangkan suhu ruang MAS ditetapkan dengan mengatur peralatan pendingin, dalam penelitian ini suhu ruang simpan yang digunakan adalah $10{ }^{\circ} \mathrm{C}, 15$ ${ }^{\circ} \mathrm{C}$, dan $28^{\circ} \mathrm{C}$. Baik komposisi gas maupun suhu ruang penyimpan MAS diatur dan dikembalikan pada kondisi kombinasi perlakuan yang ditetapkan setiap hari setelah pengambilan sampel buah tomat.

\section{Rancangan percobaan}

Rancangan percobaan yang digunakan dalam penelitian ini ialah Rancangan Acak Lengkap (Completely Rondomized Design) dengan dua faktor. Hal ini disebabkan karena lingkungan tempat percobaan relatif homogen, karena seluruh proses penelitian dilakukan di dalam laboratorium. Faktor pertama adalah variasi konsentrasi oksigen ruang simpan $(3 \%, 10 \%, 15 \%$, dan $21 \%)$ dan faktor kedua adalah variasi suhu ruang penyimpanan $\left(10{ }^{\circ} \mathrm{C}, 15^{\circ} \mathrm{C}\right.$, dan $\left.28^{\circ} \mathrm{C}\right)$, dengan demikian terdapat 12 kombinasi perlakuan. Masing-masing kombinasi perlakuan diulang sebanyak tiga kali dan setiap kombinasi perlakuan membutuhkan $56 \mathrm{~kg}$ buah tomat. Kombinasi perlakuan dapat dilihat pada Tabel 1 . 


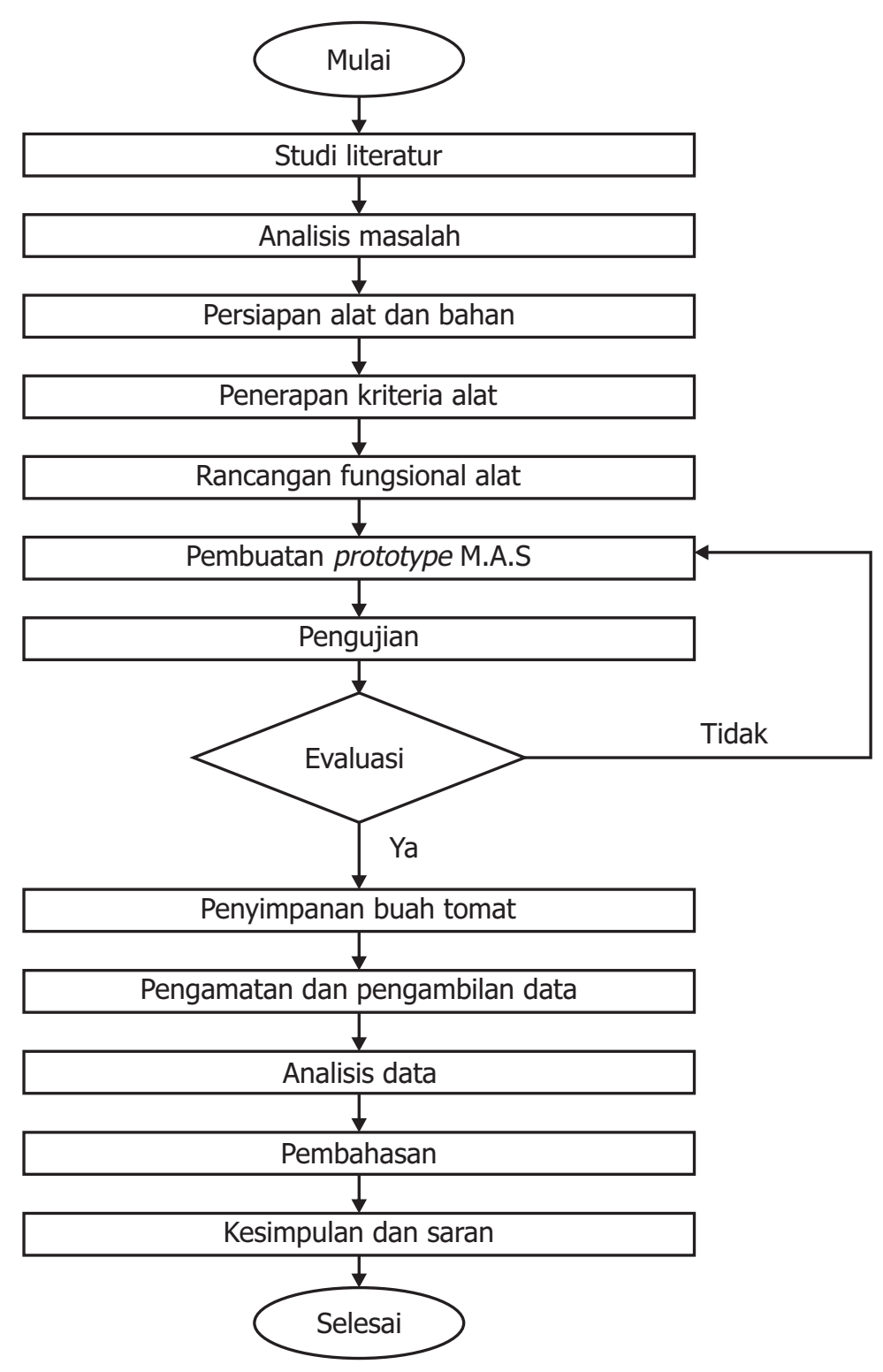

Gambar 2. Bagan alir penelitian

Tabel 1. Layout kombinasi perlakuan

\begin{tabular}{ccccc}
\hline \multirow{2}{*}{ Suhu } & \multicolumn{4}{c}{ Oksigen } \\
\cline { 2 - 5 } & $3 \%\left(\mathrm{O}_{1}\right)$ & $10 \%\left(\mathrm{O}_{2}\right)$ & $15 \%\left(\mathrm{O}_{3}\right)$ & $21 \%\left(\mathrm{O}_{4}\right)$ \\
\hline $10^{\circ} \mathrm{C}\left(\mathrm{T}_{1}\right)$ & $\mathrm{O}_{1} \mathrm{~T}_{1}$ & $\mathrm{O}_{2} \mathrm{~T}_{1}$ & $\mathrm{O}_{3} \mathrm{~T}_{1}$ & $\mathrm{O}_{4} \mathrm{~T}_{1}$ \\
$15^{\circ} \mathrm{C}\left(\mathrm{T}_{2}\right)$ & $\mathrm{O}_{1} \mathrm{~T}_{2}$ & $\mathrm{O}_{2} \mathrm{~T}_{2}$ & $\mathrm{O}_{3} \mathrm{~T}_{2}$ & $\mathrm{O}_{4} \mathrm{~T}_{2}$ \\
$28^{\circ} \mathrm{C}\left(\mathrm{T}_{3}\right)$ & $\mathrm{O}_{1} \mathrm{~T}_{3}$ & $\mathrm{O}_{2} \mathrm{~T}_{3}$ & $\mathrm{O}_{3} \mathrm{~T}_{3}$ & $\mathrm{O}_{4} \mathrm{~T}_{3}$ \\
\hline
\end{tabular}

\section{Analisis data}

Data dianalisis menggunakan software microsoft excel dan IBM SPSS Statistic 23-Free Trail. Data-data sifat fisik buah tomat yang dianalisis meliputi laju respirasi, susut bobot, kekerasan buah, total padatan terlarut dan $\mathrm{pH}$. Sebelum dianalisis dengan rancangan acak lengkap dua faktor (two way-ANOVA), data-data hasil pengamatan dilakukan uji homogennitas terlebih dahulu menggunakan Levene's test. Dari analisis rancangan acak lengkap dua faktor, maka akan dapat diketahui pengaruh konsentrasi oksigen, suhu ruang MAS, dan interaksinya terhadap parameter yang dianalisis. Apabila ada beda nyata maka dilakukan uji lanjut dengan Duncan Multiple Range Test dengan taraf signifikansi 5\%. Adapun persamaan matematis untuk analisis susut bobot dihitung dengan menggunakan Persamaan 1.

Analisis susut bobot $=\frac{(\text { massa hari ke }-0)-(\text { massa hari ke }-\mathrm{n})}{\text { massa hari ke }-0} \times 100 \%$ 


\section{HASIL DAN PEMBAHASAN}

\section{Laju Respirasi}

Pengukuran laju respirasi buah tomat selama proses penyimpanan dilakukan setiap 24 jam sekali pada jam yang sama setiap interval waktu dan dilakukan mulai dari jam ke-0 hingga jam ke-336 (hari ke-0 sampai hari ke-14) dengan menggunakan static method. Pengukuran dilakukan setiap 24 jam sekali bertujuan agar waktu pengukuran untuk semua parameter adalah seragam. Disini, data yang diambil pada saat pengamatan ialah penurunan konsentrasi oksigen dan peningkatan karbondioksida dalam respirometer. Kemudian kedua jenis data tersebut dipakai untuk menghitung laju respirasi (Tabel 2 dan 3). Secara umum terjadi penurunan oksigen dan peningkatan karbondioksida di dalam respirometer selama penyimpanan buah tomat. Kondisi yang sama juga dilaporkan oleh Aprianti dan Bintoro (2021) pada pengukuran laju respirasi buah tomat selama proses pematangan. Di dalam respirometer sistem statis, maka oksigen akan secara kontinyu dikomsumsi buah tomat, sehingga konsentrasinya menurun dan karbondioksida meningkat sebagai akibat dari akumulasi hasil respirasi yang menghasilkan karbondioksida.

Dari Tabel 2 dan 3 tersebut dapat dilihat bahwa pada penyimpanan dengan suhu lingkungan udara terbuka $\left(28^{\circ} \mathrm{C}\right)$ memberikan rata-rata laju respirasi baik dalam konsumsi oksigen maupun produksi karbondiaksida

Tabel 2. Rata-rata laju respirasi (konsumsi $\mathrm{O}_{2}$ ) selama penyimpanan

\begin{tabular}{ccccc}
\hline \multirow{2}{*}{$\begin{array}{c}\text { Suhu ruang } \\
\text { penyimpanan }\end{array}$} & \multicolumn{4}{c}{$\mathrm{RO}_{2}\left(\times 10^{-6} \mathrm{~m}^{3} / \mathrm{kg}\right.$.jam $)$} \\
\cline { 2 - 5 } & $3 \%$ & $10 \%$ & $15 \%$ & $21 \%$ \\
\hline $10^{\circ} \mathrm{C}$ & 0,48 & 0,33 & 0,70 & 2,56 \\
$15^{\circ} \mathrm{C}$ & 0,34 & 1,05 & 1,07 & 3,31 \\
$28^{\circ} \mathrm{C}$ & 0,38 & 2,56 & 2,16 & 3,78 \\
\hline
\end{tabular}

Tabel 3. Rata-rata laju respirasi (produksi $\mathrm{CO}_{2}$ ) selama penyimpanan

\begin{tabular}{ccccc}
\hline \multirow{2}{*}{$\begin{array}{c}\text { Suhu ruang } \\
\text { penyimpanan }\end{array}$} & \multicolumn{4}{c}{$\mathrm{RCO}_{2}\left(\times 10^{-6} \mathrm{~m}^{3} / \mathrm{kg} . \mathrm{jam}\right)$} \\
\cline { 2 - 5 } & $3 \%$ & $10 \%$ & $15 \%$ & $21 \%$ \\
\hline $10^{\circ} \mathrm{C}$ & 3,16 & 0,80 & 0,71 & 2,43 \\
$15^{\circ} \mathrm{C}$ & 2,56 & 4,31 & 1,00 & 3,13 \\
$28^{\circ} \mathrm{C}$ & 5,41 & 3,98 & 2,79 & 4,72 \\
\hline
\end{tabular}

yang lebih tinggi dari pada penyimpanan pada suhu yang lebih rendah. Demikian juga secara umum penyimpanan pada konsentrasi oksigen yang tinggi $(21 \%)$ cenderung memberikan laju respirasi yang tinggi pula, meskipun pada produksi karbondioksida masih belum konsisten. Namun demikian, secara umum dapat diketahui adanya kecenderungan bahwa pada penyimpanan dengan suhu $10^{\circ} \mathrm{C}$ dan $15^{\circ} \mathrm{C}$ serta konsentrasi oksigen $10 \%$ dan $15 \%$ yang merupakan kondisi modified atmosphere storage akan menghasilkan laju respirasi yang cukup rendah. Karena data laju respirasi ini merupakan ratarata dari laju respirasi selama proses penyimpanan, maka disini tidak dilakukan analisis statistik lebih lanjut. Untuk memberikan ilustrasi yang lebih lengkap, pola perubahan laju respirasi selama penyimpanan dapat dilihat pada Gambar 3. Dari penelitian ini diperoleh bahwa laju respirasi (konsumsi $\mathrm{O}_{2}$ ) terendah terjadi pada kombinasi perlakuan suhu $10^{\circ} \mathrm{C}$ dan konsentrasi oksigen $10 \%$ sedangkan untuk laju respirasi (produksi $\mathrm{CO}_{2}$ ) terendah terjadi pada kombinasi perlakuan suhu $10{ }^{\circ} \mathrm{C}$ dan oksigen $15 \%$. Sebagai perbandingan, menurut Singh (2013) laju respirasi tomat pada suhu $28{ }^{\circ} \mathrm{C}$ adalah sebesar $70 \mathrm{mg} / \mathrm{kg}$.jam dan pada suhu 15 ${ }^{\circ} \mathrm{C}$ laju respirasi tomat sebesar $15 \mathrm{mg} / \mathrm{kg}$.jam.

\section{Susut Bobot}

Pengukuran susut bobot dilakukan pada sampel buah tomat yang sama selama proses penyimpanan. Dari penelitian ini dapat diketahui, bahwa seiring dengan berjalannya waktu bobot buah tomat mengalami penurunan selama proses penyimpanan. Penyusutan bobot buah tomat juga diamati setiap hari, mulai dari hari pertama hingga hari ke 14 selama proses penyimpanan berlangsung. Gambar 4, menunjukkan persentase penurunan berat buah tomat selama penyimpanan.

Untuk keperluan analisis statistik, pada penelitian ini diambil data hasil pengamatan pada hari ke-10 untuk semua parameter, hal ini dimaksudkan bahwa pada hari ke-10 tersebut perubahan berbagai parameter fisik yang terjadi sudah cukup besar sehingga pengaruh dari perlakuan yang diberikan akan lebih jelas terlihat. Dari hasil

Tabel 4. Hasil analisis statistik susut bobot buah tomat

\begin{tabular}{ccccc}
\hline \multirow{2}{*}{ Suhu } & \multicolumn{4}{c}{ Konsentrasi $\mathrm{O}_{2}$} \\
\cline { 2 - 5 } & $3 \%$ & $10 \%$ & $15 \%$ & $21 \%$ \\
\hline $10^{\circ} \mathrm{C}$ & $4,2 \pm 0,4^{\mathrm{a}}$ & $4,8 \pm 0,2^{\mathrm{a}}$ & $8,7 \pm 3,2^{\text {ab }}$ & $3,6 \pm 0,2^{\mathrm{a}}$ \\
$15^{\circ} \mathrm{C}$ & $3,9 \pm 0,1^{\mathrm{a}}$ & $4,8 \pm 0,7^{\mathrm{a}}$ & $3,7 \pm 0,1^{\mathrm{a}}$ & $4,5 \pm 0,4^{\mathrm{a}}$ \\
$28^{\circ} \mathrm{C}$ & $17,3 \pm 9,0^{\mathrm{c}}$ & $18,2 \pm 8,4^{\mathrm{c}}$ & $16,7 \pm 8,4^{\text {bc }}$ & $15,1 \pm 5,0^{\text {bc }}$ \\
\hline
\end{tabular}

Keterangan: Superscript yang berbeda menunjukkan bahwa konsentrasi oksigen berbeda nyata pada $p<0,0$ 


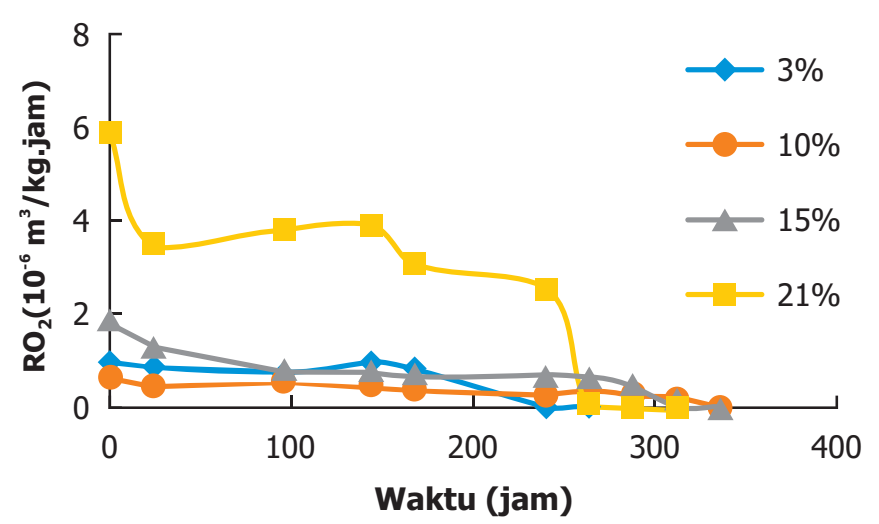

(a)

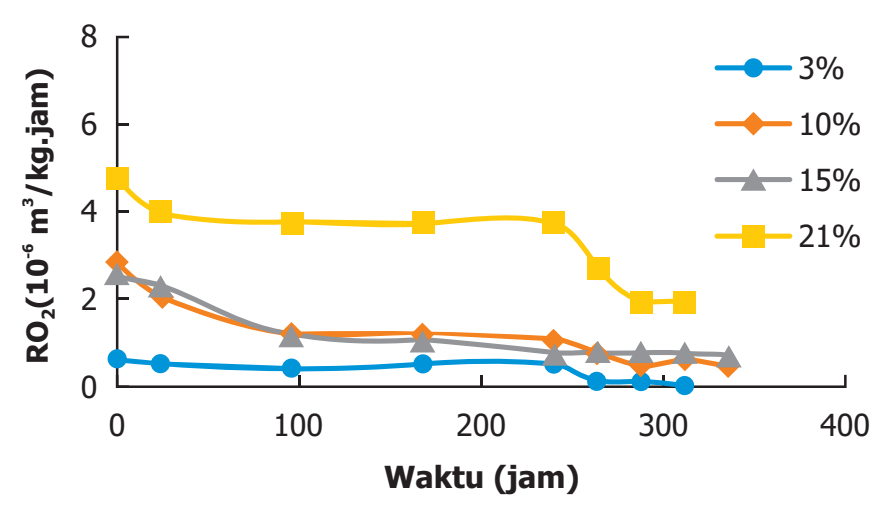

(b)

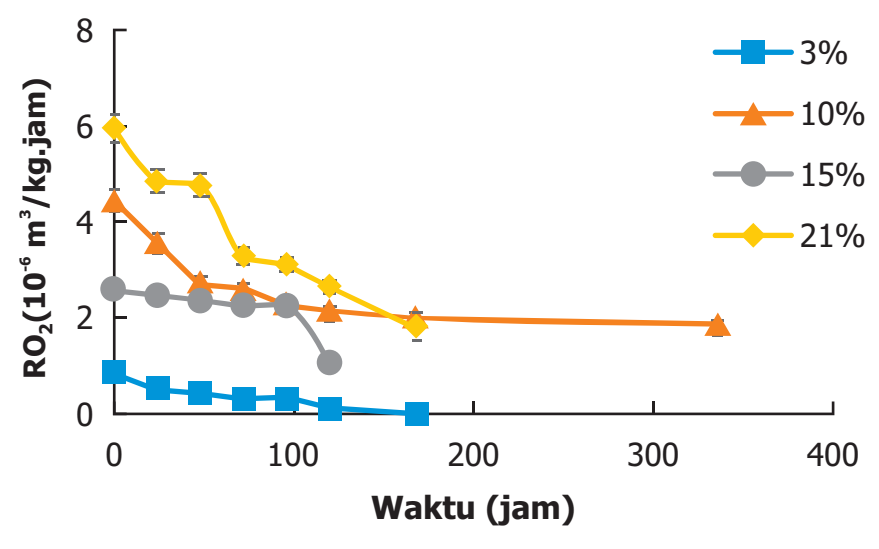

(c)

Gambar 3. Laju respirasi (konsumsi $\mathrm{O}_{2}$ ) pada suhu (a) $10{ }^{\circ} \mathrm{C}$, (b) $15^{\circ} \mathrm{C}$, dan (c) $28^{\circ} \mathrm{C}$

analisis statistik dapat diketahui bahwa interaksi antara konsentrasi oksigen dan suhu ruang simpan menunjukkan adanya pengaruh nyata terhadap penurunan susut bobot buah tomat selama peroses penyimpanan.

Dari Tabel 4 dapat diketahui bahwa perlakuan penyimpanan pada suhu $15^{\circ} \mathrm{C}$ cenderung memberikan nilai susut bobotyang paling kecil untuksemua konsentrasi

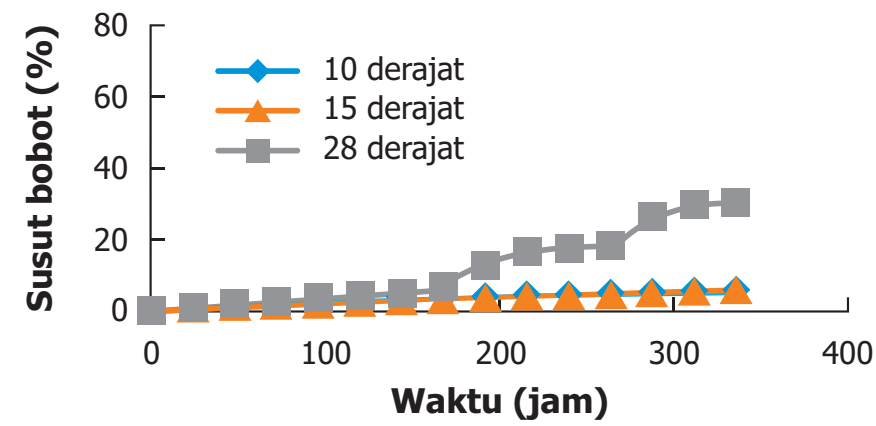

(a)

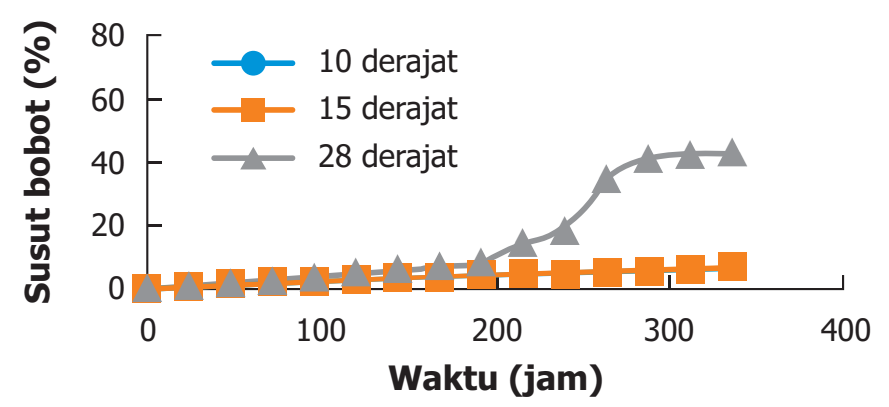

(b)

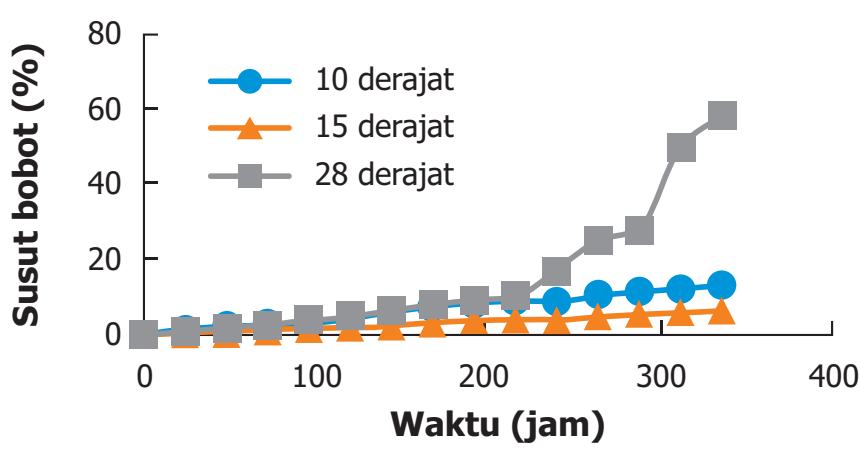

(c)

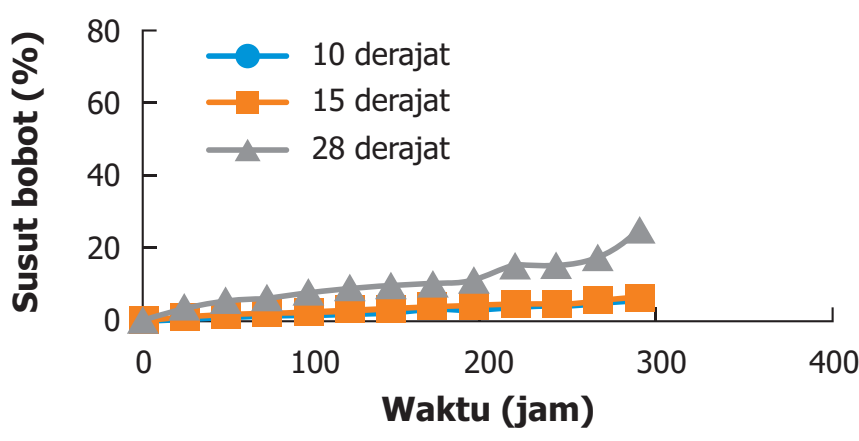

(d)

Gambar 4. Persentase susut bobot buah tomat selama penyimpanan (a) konsentrasi $\mathrm{O}_{2} 3 \%$, (b) konsentrasi $\mathrm{O}_{2} 10 \%$, (c) konsentrasi $\mathrm{O}_{2} 15 \%$, dan (d) konsentrasi $\mathrm{O}_{2} 21 \%$ 
oksigen yang digunakan. Sedangkan pada penyimpanan dengan suhu $28{ }^{\circ} \mathrm{C}$ (lingkungan) memberikan nilai susut bobot yang paling tinggi untuk semua konsentrasi oksigen yang diteliti. Hasil ini menunjukkan bahwa suhu penyimpanan mempunyai pengaruh yang kuat terhadap penurunan bobot dari buah tomat, dimana secara umum semakin rendah suhu penyimpanan maka akan semakin kecil nilai susut bobot yang terjadi. Pada penyimpanan dalam ruang terbuka ketersediaan oksigen yang melimpah dan kondisi suhu ruang yang tinggi menyebabkan laju respirasi buah tomat berjalan dengan cepat sehingga persentase susut bobot buah tomat sangat tinggi selama proses penyimpanan berlangsung (Fonseca dkk., 2002). Semakin cepat laju respirasi buah tomat menyebabkan semakin besar pula persentase susut bobot buah tomat (Sari dan Hadiyanto, 2013). Sebaliknya, kondisi ketersediaan oksigen yang rendah dalam ruang simpan disertai dengan suhu ruang yang optimum menyebabkan laju respirasi buah tomat dapat ditekan dan dihambat selama proses penyimpanan berlangsung (Chitravati dkk., 2015). Persentase susut bobot yang benilai kecil secara konsisten terjadi pada kombinasi perlakuan suhu $15^{\circ} \mathrm{C}$ untuk semua konsentrasi oksigen yang digunakan. Namun demikian, ini tidak berbeda nyata dengan beberapa kombinasi perlakuan yang lain, terutama pada penyimpanan dengan suhu $10^{\circ} \mathrm{C}$. Tetapi susut bobot pada kedua suhu tersebut secara umum lebih rendah dan berbeda nyata dengan suhu penyimpanan $28^{\circ} \mathrm{C}$. Memperhatikan hasil analisis ini, secara umum dapat diketahui bahwa suhu penyimpanan yang rendah $10^{\circ} \mathrm{C}$ dan $15^{\circ} \mathrm{C}$ terutama dengan konsentrasi oksigen yang rendah juga, akan mampu menekan susut bobot. Namun demikian, dari pengamatan secara visual pada penelitian ini, penyimpanan pada suhu $10^{\circ} \mathrm{C}$ menunjukkan bahwa Sebagian sampel buah tomat mengalami kerusakan dinding sel kulit buah yang kemungkinan ini akibat dari terjadinya chilling injury.

\section{Kekerasan Buah}

Tujuan dari pengukuran kekerasan buah ialah untuk mengetahui pengaruh suhu dan konsentrasi oksigen dalam ruang simpan terhadap kekuatan dinding sel buah tomat selama proses penyimpanan. Perubahan kekerasan buah tomat selama penyimpanan dapat dilihat pada Gambar 5.

Pada kondisi suhu ruang simpan yang dingin kulit buah tomat cenderung keras hal ini disebabkan oleh terjadi penghambatan berbagai macam aktivitas enzim yang berlangsung dalam buah tomat sehingga proses degradasi dinding sel tidak dapat berlangsung normal. Hasil analisis statistik kekerasan buah tomat selama proses penyimpanan disajikan pada Tabel 5 .
Tabel 5. Hasil analisis statistik perubahan kekerasan buah tomat

\begin{tabular}{ccccc}
\hline \multirow{2}{*}{ Suhu } & \multicolumn{4}{c}{ Konsentrasi $\mathrm{O}_{2}$} \\
\cline { 2 - 5 } & $3 \%$ & $10 \%$ & $15 \%$ & $21 \%$ \\
\hline $10^{\circ} \mathrm{C}$ & $6,7 \pm 1,1^{\mathrm{bc}}$ & $7,7 \pm 0,1^{\mathrm{c}}$ & $7,3 \pm 0,1^{\mathrm{bc}}$ & $7,0 \pm 0,2^{\mathrm{bc}}$ \\
$15^{\circ} \mathrm{C}$ & $7,4 \pm 0,0^{\mathrm{bc}}$ & $7,1 \pm 0,2^{\mathrm{bc}}$ & $7,1 \pm 0,1^{\mathrm{bc}}$ & $6,0 \pm 1,2^{\mathrm{bc}}$ \\
$28^{\circ} \mathrm{C}$ & $5,9 \pm 0,1^{\mathrm{a}}$ & $7,4 \pm 0,1^{\mathrm{bc}}$ & $7,3 \pm 0,1^{\mathrm{bc}}$ & $7,0 \pm 0,1^{\mathrm{bc}}$ \\
\hline
\end{tabular}

Keterangan: Superscript yang berbeda menunjukkan bahwa konsentrasi oksigen berbeda nyata pada $p<0,05$

Dari Tabel 5 dapat diketahui bahwa interaksi perlakuan variasi oksigen dan suhu ruang simpan berpengaruh secara signifikan terhadap perubahan kekerasan buah tomat selama proses penyimpanan. Namun demikian, perbedaan hanya terlihat pada perlakuan suhu $28{ }^{\circ} \mathrm{C}$ dengan konsentrasi oksigen $3 \%$ dan suhu $10{ }^{\circ} \mathrm{C}$ dengan konsentrasi oksigen $10 \%$, selebihnya tidak menunjukkan beda nyata. Pada kombinasi penyimpanan dengan suhu $10^{\circ} \mathrm{C}$ dan konsentrasi oksigen $10 \%$ memberikan nilai kekerasan yang paling tinggi dan berbeda nyata dengan kombinasi perlakuan yang lainnya. Kemungkinan pada kombinasi perlakuan ini, penghambatan proses-proses metabolisme yang terjadi pada buah tomat berjalan paling efektif, sehingga kekerasan buah dapat dipertahankan lebih baik. Sedangkan nilai kekerasan buah tomat terendah terdapat pada kombinasi perlakuan oksigen 3\% pada kondisi suhu ruang $28^{\circ} \mathrm{C}$. Triardianto dan Bintoro (2021), melaporkan bahwa kekerasan buah pisang mas yang mendapatkan perlakuan ozon menurun seiring dengan waktu penyimpanan, pada penyimpanan dengan suhu $5{ }^{\circ} \mathrm{C}$ laju penurunannya lebih rendah dibandingkan dengan penyimpanan pada suhu $15^{\circ} \mathrm{C}$ dan $27^{\circ} \mathrm{C}$.

\section{Total Padatan Terlarut}

Total padatan terlarut pada produk hortikultura cenderung meningkat dari waktu ke waktu hal ini disebabkan oleh asam organik dalam buah dan sayuran terus mengalami degradasi dan kemudian diubah menjadi gula (Hakim dkk., 2012). Total padatan terlarut dari semua perlakuan pada pematangan buah pisang dengan menggunkan tiga macam ripening agent meningkat seiring dengan lama waktu penyimpanan pada kondisi ruang terbuka (Khairuddin dan Bintoro, 2021). Namun demikian, nilai total padatan terlarut dalam penelitian ini masih cenderung fluktuatif namun terus menurun ketika memasuki interval waktu beberapa hari terakhir. Kecenderungan penurunan nilai padatan terlarut dari penelitian ini kemungkinan disebabkan karena kondisi atmosphere ruang penyimpanan yang 


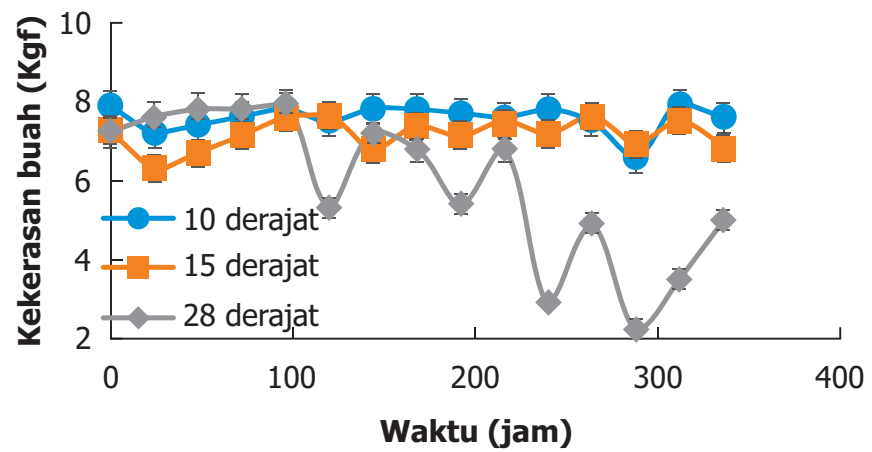

(a)

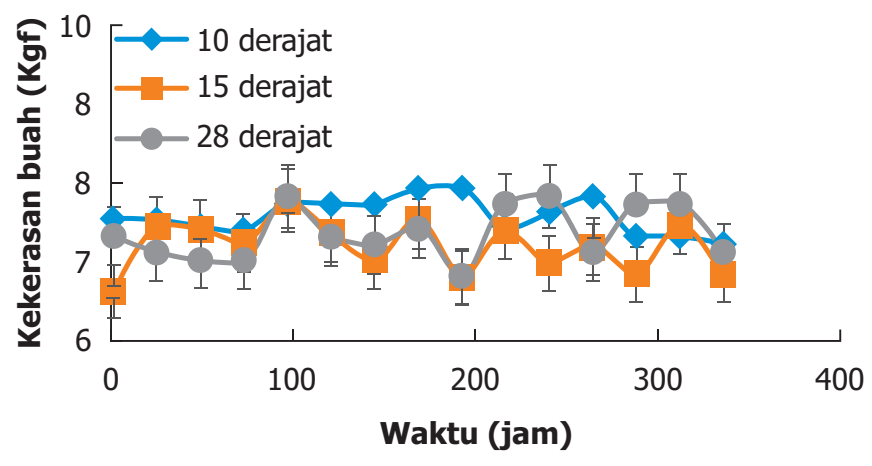

(b)

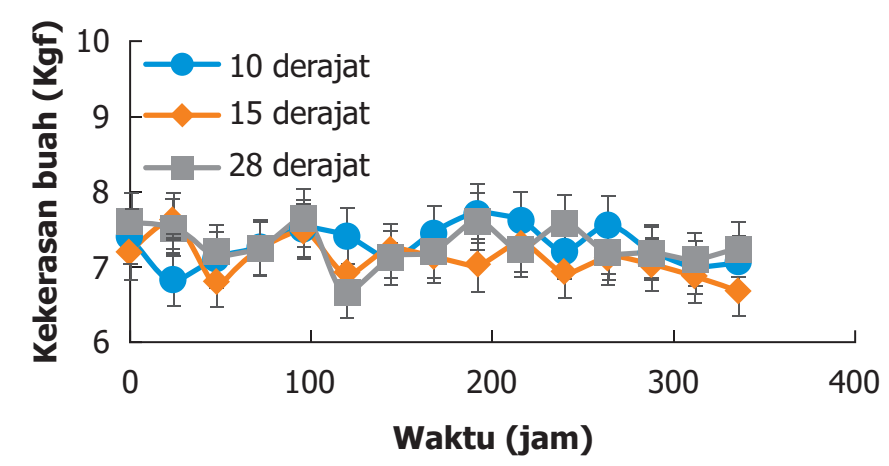

(c)

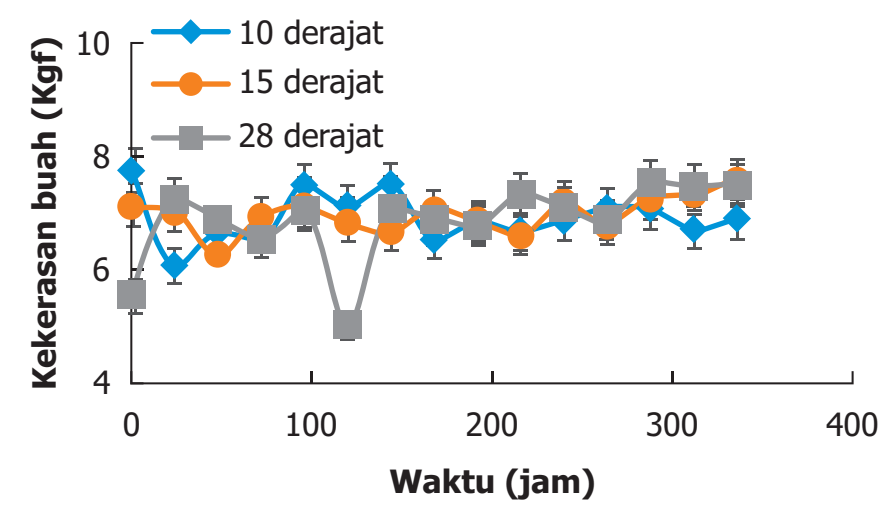

(d)

Gambar 5. Perubahan kekerasan buah tomat selama penyimpanan (a) konsentrasi $\mathrm{O}_{2} 3 \%$, (b) konsentrasi $\mathrm{O}_{2} 10 \%$, (c) konsentrasi $\mathrm{O}_{2} 15 \%$, dan (d) konsentrasi $\mathrm{O}_{2} 21 \%$ berbeda dengan dua penelitian tersebut di atas. Hasil analisis statistik perubahan total padatan terlarut buah tomat selama proses penyimpanan disajikan pada Tabel 6.

Tabel 6. Hasil analisis statistik total padatan terlarut buah tomat

\begin{tabular}{ccccc}
\hline \multirow{2}{*}{ Suhu } & \multicolumn{4}{c}{ Konsentrasi $\mathrm{O}_{2}$} \\
\cline { 2 - 5 } & $3 \%$ & $10 \%$ & $15 \%$ & $21 \%$ \\
\hline $10^{\circ} \mathrm{C}$ & $3,79 \pm 0,0^{\mathrm{ab}}$ & $4,02 \pm 0,0^{\mathrm{bc}}$ & $3,98 \pm 0,1^{\mathrm{abc}}$ & $4,06 \pm 0,1^{\mathrm{bc}}$ \\
$15^{\circ} \mathrm{C}$ & $3,92 \pm 0,0^{\mathrm{abc}}$ & $3,52 \pm 0,5^{\mathrm{a}}$ & $4,02 \pm 0,1^{\mathrm{bc}}$ & $4,03 \pm 0,1^{\mathrm{bc}}$ \\
$28^{\circ} \mathrm{C}$ & $3,99 \pm 0,0^{\mathrm{bc}}$ & $4,10 \pm 0,1^{\mathrm{c}}$ & $3,96 \pm 0,2^{\mathrm{abc}}$ & $4,02 \pm 0,1^{\mathrm{bc}}$ \\
\hline
\end{tabular}

Keterangan: Superscript yang berbeda menunjukkan bahwa konsentrasi oksigen berbeda nyata pada $p<0,05$

Interaksi antara konsentrasi oksigen dan suhu ruang simpan berpengaruh nyata terhadap parameter total padatan terlarut. Kondisi ini menunjukkan bahwa efek suhu penyimpanan terhadap perubahan total padatan terlarut juga dipengaruhi oleh tingkat konsentrasi oksigen di dalam ruang penyimpanan. Dari Tabel 6 dapat diketahui bahwa nilai padatan terlarut paling rendah terjadi pada kombinasi perlakuan konsentrasi oksigen $10 \%$ dan suhu penyimpanan $15^{\circ} \mathrm{C}$. Namun demikian, kombinasi perlakuan ini tidak berbeda nyata dengan konsentrasi oksigen $3 \%$ pada suhu 10 ${ }^{\circ} \mathrm{C}$ dan $15{ }^{\circ} \mathrm{C}$ dan konsentrasi oksigen $15 \%$ suhu $10^{\circ} \mathrm{C}$ dan $28^{\circ} \mathrm{C}$. Hasil ini dapat diamati lebih jauh, bahwa secara umum konsentrasi oksigen yang lebih rendah dari udara terbuka (21\%) dan suhu yang cenderung rendah $\left(10^{\circ} \mathrm{C}\right.$ atau $\left.15^{\circ} \mathrm{C}\right)$ akan memberikan perubahan nilai padatan terlarut yang lebih rendah. Sedangkan pada konsentrasi oksigen $21 \%$ pada semua suhu penyimpanan menunjukkan nilai padatan terlarut yang paling besar.

\section{Tingkat Keasaman (pH)}

Pengukuran terhadap tingkat keasaman/ potential hydrogen $(\mathrm{pH})$ bertujuan untuk mengetahui perubahan kadar keasaman buah tomat selama proses penyimpanan. Tinggi rendahnya $\mathrm{pH}$ buah tomat dapat digunakan untuk mengetahui perubahan tingkat keasaman buah tomat selama proses penyimpanan. Hasil analisis statistik perubahan $\mathrm{pH}$ buah tomat selama proses penyimpanan disajikan pada Tabel 7.

Dari Tabel 7 dapat diketahui bahwa nilai $\mathrm{pH}$ terendah diperoleh pada kombinasi perlakuan konsentrasi oksigen $10 \%$ dengan suhu penyimpanan $15^{\circ} \mathrm{C}$, tetapi tidak berbeda nyata dengan konsentrasi oksigen $3 \%$ pada suhu $10{ }^{\circ} \mathrm{C}$ dan $15{ }^{\circ} \mathrm{C}$ serta dengan 
Tabel 7. Hasil analisis statistik pH buah tomat

\begin{tabular}{ccccc}
\hline \multirow{2}{*}{ Suhu } & \multicolumn{4}{c}{ Konsentrasi $\mathrm{O}_{2}$} \\
\cline { 2 - 5 } & $3 \%$ & $10 \%$ & $15 \%$ & $21 \%$ \\
\hline $10^{\circ} \mathrm{C}$ & $3,83 \pm 0,06^{\mathrm{ab}}$ & $4,04 \pm 0,07^{\mathrm{bc}}$ & $3,94 \pm 0,17^{\mathrm{abc}}$ & $4,03 \pm 0,12^{\mathrm{bc}}$ \\
$15^{\circ} \mathrm{C}$ & $3,83 \pm 0,06^{\mathrm{abc}}$ & $3,80 \pm 0,09^{\mathrm{a}}$ & $4,01 \pm 0,12^{\mathrm{bc}}$ & $4,00 \pm 0,10^{\mathrm{bc}}$ \\
$28^{\circ} \mathrm{C}$ & $4,12 \pm 0,13^{\mathrm{bc}}$ & $4,10 \pm 0,10^{\mathrm{c}}$ & $3,93 \pm 0,15^{\mathrm{abc}}$ & $4,00 \pm 0,10^{\mathrm{bc}}$ \\
\hline
\end{tabular}

Keterangan: Superscript yang berbeda menunjukkan bahwa konsentrasi oksigen berbeda nyata pada $p<0,05$

konsentrasi oksigen $15 \%$ suhu $15^{\circ} \mathrm{C}$ dan $28^{\circ} \mathrm{C}$. Kondisi yang hampir sama dengan hasil pengamatan yang terjadi pada parameter padatan terlarut, yaitu adanya kecenderungan bahwa pada konsentrasi oksigen dibawah $21 \%$ dan suhu ruang simpan dibawah suhu udara terbuka, memberikan nilai pH yang lebih rendah. Sedangkan pada konsentrasi oksigen $21 \%$ untuk semua suhu penyimpanan, cenderung memberikan nilai $\mathrm{pH}$ yang paling tinggi. Beckles (2012), menyatakan bahwa kebusukkan buah tomat dapat ditangani dengan penyimpanan pascapanen pada suhu $12,5{ }^{\circ} \mathrm{C}$, yang merupakan strategi yang paling effektif dan sederhana. Lebih jauh, modifikasi atmosphere (konsentrasi oksigen $4 \%$ diimbangi dengan gas nitrogen dan kelembaban yang tinggi, yaitu diatas $85 \%$ ) bersamaan dengan suhu yang rendah akan dapat memperlambat proses kematangan.

\section{KESIMPULAN}

Peralatan Modified Atmosphere Storage (MAS) dapat dibuat dari bahan-bahan yang tersedia di pasaran lokal dengan hasil yang memuaskan. Salah satu keperluan dalam penyimpanan produk segar yaitu penurunan konsentrasi oksigen dalam ruang penyimpanan dapat dilakukan dengan mengalirkan gas nitrogen kedalam ruang simpan MAS tersebut sesuai dengan kebutuhan. Kombinasi perlakuan variasi konsentrasi oksigen dan variasi suhu ruang penyimpanan berpengaruh terhadap parameter laju respirasi, susut bobot, total padatan terlarut, $\mathrm{pH}$, dan kekerasan buah tomat. Berdasarkan hasil analisis statistik secara keseluruhan untuk semua parameter dalam penelitian ini, secara umum kombinasi perlakuan terbaik adalah perlakuan konsentrasi oksigen $10 \%$ dan suhu $15^{\circ} \mathrm{C}$.

\section{SARAN}

Diharapkan penelitian ini dapat dilanjutkan dengan menerapkan sistem otomatisasi pada alat MAS yang telah dibangun dan dilanjutkan dengan melakukan analisis kinerja alat dan aplikasinya untuk penyimpanan produk segar yang lebih luas lagi.

\section{UCAPAN TERIMA KASIH}

Ucapan terima kasih yang sebesar-besarnya ditujukan kepada Universitas Gadjah Mada yang telah memberikan dukungan sebagian dana penelitian melalui program Rekognisi Tugas Akhir (RTA).

\section{KONFLIK KEPENTINGAN}

Tidak ada konflik kepentingan antara penulis maupun pihak lain dalam penerbitan manuskrip ini.

\section{DAFTAR PUSTAKA}

Aprianti, S dan Bintoro, N. (2021). The effect of concentrations and exposure durations of ethylene gas on the respiration rate of tomato fruit (Solanum lycopersicum). The 2nd International Conference on Sustainable Agriculture for Rural Development (2nd ICSARD). IOP Conf. Series: Earth and Environmental Science 653. IOP Publishing. doi:10.1088/1755-1315/653/1/01202.

Beckles, D.M. (2012). Factors affecting the postharvest soluble solid content and sugar content of tomato (Solanum lycopersicum L) fruit. Postharvest Biology and Technology. 63: 129-140.

Chitravati, K., Chauhan O.P., dan Raju, P.S. (2015). Influence of modified atmosphere packaging on self-life of green chillies (Capsicum annum L.). Food Pacakging and Self-Life (4): 1-9. ISSN :2214-2894. doi: 10.1016/j. fpsl.2015.02.001

Fonseca, S.C., Oliveira, F.A.R., Frias, J.M., Brecht, J.K., dan Chau, K.V. (2002). Modelling respiration rate of shredded galega kale for development of modified atmosphere packaging. Journal of Food Engineering 54 (4): 299-307.

Hakim, K.A., Islam, M.K., Ibrahim, M., Hossain, M.J. Ara N.A., dan Haque, M.F. (2012). Status of the behavioral pattern of biochemical properties of banana in the storage condition. International Journal of Bioscience (IJB). 2(8): 83-94.

Khairuddin, A dan Bintoro, N. (2021). Kinetics analysis of the effect of types and concentrations of ripening agents on the physical quality changes of banana fruit (Musa acuminata Colla). The 2nd International Conference on Sustainable Agriculture for Rural Development (2nd ICSARD). IOP Conf. Series: Earth and Environmental Science 653. IOP Publishing. doi:10.1088/17551315/653/1/012025. 
Luntungan, A.Y. (2012). Analisis tingkat pendapatan usaha tani tomat apel di kecamatan tompaso Kabupaten Minahasa. Jurnal Pembangunan Ekonomi dan Keuangan Daerah (PEKD). 7(3): 1-25

Mama, S., Yemer, J., dan Woelore, W. (2016). Effect of hot water treatments on shelf life of tomato (Lycopersicon esculentum Mill). Journal of Natural Sciences Research. 6(17): 69-77.

Rahayu, D., dan Bintoro, N. (2019). Mathematical analysis and modelling of respiration rate of tropical climacteric produces during storage under various temperatures. The 3rd International Symposium on Agricultural and Biosystem Engineering. IOP Conf. Series: Earth and Environmental Science 355. IOP Publishing. doi:10.1088/1755-1315/355/1/012034.
Sari, D.A., dan Hadiyanto, H. (2013). Teknologi dan metode penyimpanan makanan sebagai upaya memperpanjang shelf life. Jurnal Aplikasi Teknologi Pangan, 2 (2): 52-59.

Singh, R. (2013). Respiratory behavior of turning stage mature tomato under closed system at different temperature. Journal Food Science Technology. 5(2): 78-84.

Triardianto, D. dan Bintoro, N. (2021). The effect of different time durations of ozone treatment and storage temperatures on postharvest quality of banana (Musa acuminata). The 2nd International Conference on Sustainable Agriculture for Rural Development (2nd ICSARD). IOP Conf. Series: Earth and Environmental Science 653. IOP Publishing. doi:10.1088/1755$1315 / 759 / 1 / 012012$. 